\title{
Lidija Nikolić
}

doi: 10.19090/zop.2018.27.53-84

Sveučilište u Osijeku, Fakultet za odgojne i

UDC: $371.13: 78$

obrazovne znanosti, Republika Hrvatska

159.947.5:78

Ivana Šenk

Pregledni rad

Glazbena škola Ivana Matetića-Ronjgova

Pula, Republika Hrvatska

\section{MOTIVACIJA ZA UČENJE GLAZBE KOD STUDENATA UČITELJSKIH STUDIJA KROZ PERSPEKTIVU TEORIJA MOTIVACIJE*}

\begin{abstract}
Apstrakt. U radu se razmatra problem motivacije studenata za učenje glazbe u kontekstu obaveznoga glazbenog obrazovanja na studijima za buduće učitelje razredne nastave. Namjera je uputiti na čimbenike motivacije studenata za učenje glazbe kako bi nastava glazbe na učiteljskom studiju bila što učinkovitija te kako bi se olakšalo stjecanje kompetencija za vođenje nastave glazbe budućih učitelja. Predstavljene su tri teorije motivacije koje se konceptualno mogu primijeniti na motivaciju studenata, budućih učitelja za učenje glazbe na studiju, a to su atribucijska teorija, teorija ciljne orijentacije i teorija očekivanja-vrednovanja. Primjenom navedenih teorija na kontekst učenja glazbe na učiteljskim studijima istaknule su se varijable percepcije sposobnosti studenata, ulaganja truda, uspješnosti, afektivne i vrijednosne komponente motivacije. Teorija koja obuhvaća najviše elemenata važnih za glazbeno obrazovanje studenata učiteljskih studija jest teorija očekivanja-vrednovanja koja bi se mogla rabiti u budućim istraživanjima. Pregled dosadašnjih istraživanja motivacije u glazbenom obrazovanju pokazao je kako nastavnici mogu djelovati na povećanje motivacije za učenje glazbe ohrabrivanjem studenata na usvajanje atribucija vezanih uz ulaganje truda, poticanjem ciljne orijentacije studenata prema ciljevima učenja, omogućavanjem uspješnosti studenata u glazbi, ponudom brojnih i različitih glazbenih zadataka, ocjenjivanjem studenata temeljem uloženoga truda te sustavnim djelovanjem na razvoj vrijednosne komponente stavova studenata o glazbenom obrazovanju.
\end{abstract}

Ključne riječi: atribucije ulaganja truda, glazbeno obrazovanje, motivacija za učenje glazbe, percepcija glazbenih sposobnosti, studenti učiteljskoga studija.

\footnotetext{
*Lidija Nikolić, $\underline{\text { nnikolic@ foozos.hr }}$
} 


\section{UVOD}

Temeljni unutrašnji uvjet čovjekova učenja njegove su sposobnosti, stoga su glazbene sposobnosti neupitno osnovni preduvjet učenja glazbe. Drugi unutrašnji uvjet učenja čini motivacija. Motivacija je unutarnje stanje koje pobuđuje, upravlja i održava ponašanje (Woolfolk, 2010: 411). Istraživanja pokazuju da se $12-27 \%$ glazbenoga postignuća može objasniti djelovanjem motivacije $\mathrm{i}$ to kada se radi o različitim područjima bavljenja glazbom (Asmus, 1986a, 72). „Motivacija ima integerativnu funkciju u tom smislu što, usmjeravajući djelatnost prema određenom cilju, objedinjuje sve procese u cjelinu, kao i kapacitete ličnosti relevantne za dostizanje odabranog cilja u okvirima glazbene uspješnosti““ (Bogunović, 2010: 107). Iskustvo u vezi s nastavom glazbe na učiteljskom studiju pokazuje da studenti koji žele biti odlični i postati kompetentni učitelji, ulažu veće napore u svladavanje glazbenih zadataka i u vježbanje glazbenih vještina. Stoga će, između ostalih uvjeta, angažman studenata, budućih učitelja razredne nastave za stjecanje i razvoj glazbenih kompetencija ovisiti i o motivaciji s obzirom na to da o njezinom stupnju, kvaliteti i načinu izražavanja ovisi učenje uopće, kao i učenje glazbe.

Kada se govori o učenju glazbe, najčešće se podrazumijeva da glazbu biraju i uče oni koji to žele. Međutim, ako adolescenti i odrasle osobe u svrhu stjecanja profesionalnih kompetencija za podučavanje glazbe $\mathrm{u}$ razredu moraju učiti glazbu na studiju, onda motivacija za učenje glazbe postaje vrlo važno pitanje za nastavnike glazbe na studijima za buduće učitelje jer studenti, uz kompetencije iz različitih područja obrazovanja, trebaju steći i kompetencije u glazbi. Rezultati istraživanja glazbenoga iskustva studenata učiteljskoga studija u Hrvatskoj pokazuju kako studenti prije studija nemaju 
glazbeno obrazovanje osim u okviru općeobrazovnoga sustava (Nikolić i Ercegovac-Jagnjić, 2010: 26). Broj je studenata koji su pohađali glazbenu školu (3\%) i onih koji su privatno učili svirati (2\%) zanemariv, a $65 \%$ studenata nikada nije bilo aktivno ni u kojem ansamblu (Nikolić, 2018). Dakle, veći broj studenata nije imao zanimanje za bavljenje glazbom tijekom ranijega školovanja te nisu iskoristili mogućnosti pohađanja glazbene škole, ponuđenih izvannastavnih glazbenih aktivnosti u općeobrazovnoj školi niti onih koje pruža društvena zajednica (kulturno-umjetnička društva, crkvene zajednice, privatna glazbena poduka).

Priroda procesa učenja glazbe na učiteljskom studiju zahtijeva od studenata redovito pohađanje nastave, aktivno sudjelovanje u nastavnim aktivnostima, samostalno učenje kod kuće i svakodnevno vježbanje glazbenih vještina (sviranja jednoga glazbenog instrumenta i pjevanja). S obzirom na konceptualnu usmjerenost nastave glazbe u općem obrazovanju u Hrvatskoj na slušanje glazbe i skromnu satnicu nastavnoga predmeta Glazbene kulture i Glazbene umjetnosti, veći se dio studenata po prvi put susreće $s$ glazbenom pismenošću i izvođenjem glazbe te stjecanjem i razvojem drugih glazbenih (aktivno slušanje, sviranje, pjevanje) i metodičkih kompetencija (znanja, vještine i iskustva iz metodike nastave glazbe) tek na studiju. Iako se od studenata, budućih učitelja ne očekuju visoka glazbena postignuća, svakodnevno vježbanje sviranja i pjevanja iziskuje veći i drugačiji angažman u odnosu na onaj na koji su naviknuli tijekom ranijega školovanja. Učenje glazbenih znanja i vještina koje počinje tek na studiju, umjesto u dječjoj dobi, traži dodatni napor u učenju, a vremenska ograničenost glazbenoga obrazovanja na studiju i nastava glazbe koja se održava u velikim skupinama (Nikolić, 2017a: 165) također su otežavajući 
čimbenici. Studentima bez ranijega iskustva muziciranja nepoznate su specifičnosti učenja glazbe za koje je potrebna disciplina, upornost i dugotrajan rad. Nastavnici glazbe na učiteljskim studijima u Hrvatskoj ističu problem slabih radnih navika studenata, a sami studenti ističu kako je na učiteljskom studiju značajna poteškoća njihova nezainteresiranost za učenje glazbe (Nikolić, 2017a: 175). Osim spomenutih otežavajućih okolnosti za glazbeno obrazovanje na učiteljskim studijima, značajno je spomenuti i nisku razinu razvijenosti glazbenih sposobnosti kao pretpostavke uspješnom usvajanju glazbenih kompetencija (Nikolić, 2017a: 175; Nikolić, 2018) te ranije formirane stavove studenata o glazbi i glazbenom obrazovanju koji često nisu pogodni za njihov budući angažman u nastavi glazbe na studiju (Nikolić, 2014: 96).

Istraživanje motivacije za učenje glazbe na učiteljskim studijima te odnosa motivacije i glazbenih postignuća pomoglo bi razumijevanju prirode stjecanja i razvoja kompetencija studenata, budućih učitelja za poučavanje glazbe u razredu. Svrha je ovoga rada je uputiti na čimbenike koji utječu na motivaciju studenata za učenje glazbe tijekom glazbenoga obrazovanja na učiteljskom studiju.

Ciljevi su rada:

1) predstaviti pojedine teorije i koncepte motivacije koji bi mogli objasniti čimbenike motivacije u glazbenom obrazovanju na studijima za buduće učitelje

2) istražiti može li se i kako tijekom nastavnoga procesa djelovati na povećanje motivacije za učenje glazbe kod studenata učiteljskih studija. 


\section{MOTIVACIJA ZA UČENJE GLAZBE}

Danas se u psihologiji motivacija najčešće definira kao proces pokretanja aktivnosti čovjeka, usmjeravanja na određene objekte i reguliranje aktivnosti radi postizanja određenih ciljeva (Bogunović, 2010: 107). Istraživanja motivacije usmjerena su na uzrok i način pokretanja ciljno usmjerenih aktivnosti, intenzitet uključenosti $u$ aktivnosti, upornost $u$ pokušajima postizanja željenih ciljeva te misli i osjećaja prilikom tih procesa (Woolfolk, 2010: 411).

Teorijski okvir u kojemu se proučava motivacija za učenje glazbe obuhvaća stajališta od prevladane biheviorističke perspektive koja ističe nastavnika kao prvi izvor motivacije do teorija koje se temelje na kognitivnim teorijama motivacije postignuća (Bogunović, 2010: 109). Suvremeni modeli motivacije za glazbu prepoznaju složenost interakcije između okolinskih (kulturnih, institucionalnih, obiteljskih, obrazovnih) i unutrašnjih čimbenika (kognitivno funkcioniranje i afekt) u djelovanju na povećavanje ili smanjivanje motivacije (Hallam et al., 2016: 528). Istraživane su veze između motivacije, samopoimanja, atribucija uspjeha i neuspjeha, strukture ciljeva i uključenosti u glazbu te odustajanja od učenja glazbe (BERA, 2004: 251). U dosadašnjim studijama istraživane su brojne individualne razlike koje mogu utjecati na motivaciju za učenje glazbe među kojima su glazbene sposobnosti (Asmus i Harrison, 1990; Levitin, 2012), stavovi (Hallam, 2013; Klinedinst, 1991), individualnost (Gaunt \& Hallam, 2009), socioekonomski status (Corenblum \& Marshall, 1998; Dibben, 2006; McPherson, Osborne, Barrett, Davidson \& Faulkner, 2015), strukture ciljeva (Austin, 1991; Marjoribanks \& Mboya, 2004) i kurikul (Winter, 2004). 
Nijedna teorija motivacije sama za sebe ne može objasniti složenu strukturu motivacije pojedinca za učenje glazbe i postignuća u glazbi. Međutim, unatoč različitim pristupima pojedinih teorija važno je uvidjeti jedinstveni doprinos svake pojedine teorije u odnosu na različite aspekte $s$ kojih se promatra motivacija za učenje glazbe kako bi se dobila jasnija slika o tome o čemu ona ovisi i na koji se način može djelovati na nju u glazbenopedagoškom radu. Najznačajnije teorije rabljene u empirijskim istraživanjima, tumačenju i razumijevanju motivacije za učenje glazbe jesu atribucijska teorija (engl. attribution theory; Weiner, 1986), teorija očekivanja-vrednovanja (engl. expectancy-value theory; Atkinson, 1964; Wigfield \& Eccles, 2000), teorija ciljne orijentacije (engl. achievement goal theory; Ames, 1992), teorija intrinzične motivacije (engl. intrinsic motivation theory; Deci \& Ryan, 1985), teorija tijeka (engl. flow; Csikszentmihalyi, 1991), koncept samoučinkovitosti (engl. self-efficacy; Bandura, 1994), teorija motivacije ovladavanja (engl. mastery-oriented motivation; Dweck \& Leggett, 1988) i teorija samoodređenja (engl. self-determination theory; Ryan $\&$ Deci, 2000) (Tablica 1.).

Tablica 1. Istraživanja motivacije za učenje glazbe

Teorije Istraživanja

Asmus, 1985, 1986a, 1986b; Arnold, 1997; Austin

a atribucijska teorija \& Vispoel; 1998; Bačlija Sušić i Županić Benić, 2017; Bogunović, 2005; Schneider Grings \& Hentschke, 2015

b teorija očekivanja-
vrednovanja

Leung, 2008; McCormick \& McPherson, 2007;

McPherson \& O'Neill, 2010; McPherson,

Osborne, Barrett, Davidson \& Faulkner, 2015; 
Wigfield et al., 1997; Wigfield \& Eccles, 2000;

teorija ciljne
orijentacije

Miksza, Tan i Dye, 2016; Schmidt, 2005;

Sandene, 1997, Anguiano, 2006, Bailey, 2006

prema West, 2013

Alexander, 2015; Austin, 1988; Bangs, 1992

d teorija intrinzične

motivacije prema West, 2013

Chirico et al., 2015; Custodero, 2011; Iusca, 2015;

e teorija,,tijeka“ O'Neill, 1999; Sinnamon, Moran i O'Connell, 2012; Torres Delgado, 2017

\begin{tabular}{lll}
\hline f & koncept & Hendricks, 2016; McPherson \& McCormick, \\
samoučinkovitosti & 2006; Nielsen, 2004;
\end{tabular}

$\mathrm{g} \begin{aligned} & \text { teorija motivacije } \\ & \text { ovladavanja }\end{aligned}$

\begin{tabular}{lll}
\hline h & $\begin{array}{l}\text { teorija } \\
\text { samoodređenja }\end{array}$ & Evans, 2015; Evans \& Bonneville-Roussy, 2015; \\
& MacIntyre, Schnare \& Ross, 2017
\end{tabular}

U fokusu je našeg zanimanja populacija studenata učiteljskog studija od kojih se ne očekuje darovitost u glazbi, čija glazbena postignuća nisu visoka i njihovo glazbeno obrazovanje traje relativno kratko u odnosu na akademske glazbenike te zbog toga smatramo kako se iz teorija koje su korištene za istraživanje motivacije darovitih (Tablica 1. pod d, e, f, g, h) ne mogu izvesti značajne implikacije za glazbeno-pedagoški rad na učiteljskom studiju. Teorije motivacije koje su korištene prilikom istraživanja motivacije na uzorku učenika i studenata glazbe u širokom rasponu godina od predškolske dobi do adolescencije te za različite oblike glazbenog 
obrazovanja i time pogodnije za proučavanje motivacije za učenje glazbe kod studenata učiteljkog studija su (a) atribucijska teorija, (b) teorija ciljne orijentacije i (c) teorija očekivanja-vrednovanja (Tablica 1.).

Istraživanje motivacije različitim konceptualnim pristupima pokazalo je kako različite teorije imaju zajedničke komponente (primjerice: teorija intrinzične motivacije i teorija tijeka prema West, 2013: 14; teorije samoregulacije i teorija očekivanja-vrednovanja prema Eccles \& Wigfield, 2002: 126) ili se motivacija u glazbenom obrazovanju pokušava objasniti uporabom pristupa više teorija motivacije (primjerice teorije očekivanjavrednovanja i teorije tijeka u Burakovom, 2014 istraživanju) i utoliko se mogu integrirati kako bi se objasnila motivacija za konkretnu aktivnost i specifičnosti uvjeta za tu aktivnost. Stoga, izložit ćemo odabrana tri pristupa motivaciji s uvažavanjem komponenata svake od njih kako bismo rasvijetlili motivaciju za učenje glazbe kod studenata učiteljskoga studija.

\section{Atribucijska teorija u kontekstu učenja glazbe}

Prema atribucijskoj teoriji, ključna odrednica postignuća pojedinca njegova je percepcija uzroka uspjeha ili neuspjeha, o čemu će ovisiti i njegovo pristupanje zadatku u budućnosti (Asmus, 1986a: 71). Weiner (1986: 50) analizira atribucije postignuća u odnosu na tri ključne dimenzije: mjesto uzroka (unutrašnji ili vanjski smještaj), stabilnost uzroka (stabilnost ili nestabilnost) i mogućnost kontrole (mogućnost ili nemogućnost kontrole). U okviru spomenutih dimenzija Weiner (1986: 248) definira nekoliko glavnih uzročnih kategorija uspjeha, odnosno neuspjeha, a to su sposobnost, zalaganje, težina zadatka, sreća i raspoloženje. Stoga, kada se govori o školskim situacijama postignuća, način na koji učenici objašnjavaju svoj uspjeh ili neuspjeh određuje njihova očekivanja $\mathrm{u}$ vezi $\mathrm{s}$ budućim 
postignućima. Različita su istraživanja pokazala kako atribucije ovise o razini postignuća koju pojedinac želi postići, ali su također povezane s različitim karakteristikama pojedinaca kao što su spol, samopouzdanje, lokus kontrole (oni koji uzroke traže u unutrašnjim ili vanjskim razlozima) i socioekonomski status (Asmus, 1986a: 74).

Ako temeljno načelo teorije atribucije primijenimo na glazbeno obrazovanje, onda možemo pretpostaviti da će uvjerenja učenika o uzrocima uspjeha i neuspjeha na glazbenom zadatku utjecati na to kako će pristupiti zadatku u budućnosti (Asmus, 1986b: 274). Istraživanja atribucija učenika i studenata u kontekstu glazbenoga obrazovanja u primarnom, sekundarnom i tercijarnom obrazovanju pokazala su kako oni navode brojne tradicionalne i netradicionalne atribucije kada objašnjavaju svoja postignuća u glazbi, a najčešće su navođene atribucije one koje se tiču sposobnosti i uloženoga truda (Austin \& Vispoel, 1998: 31). Učenici mijenjaju svoje atribucije kako postaju stariji (Asmus, 1986b: 274). Mlađi su učenici skloniji vjerovanju da njihova glazbena uspješnost ovisi o vježbanju, dok se to uvjerenje odrastanjem mijenja $u$ stavove koji glazbenu uspješnost pripisuju sposobnosti. Asmus (1986b: 275) zaključuje da nastavnici na svim razinama trebaju ohrabrivati učenike na usvajanje atribucija vezanih za ulaganje truda kako bi bili motivirani da ulože više truda i tako postali kompetentni u glazbi. Nastavnici koji promoviraju stajalište da učenici mogu uspjeti u glazbi ako se potrude i revnosno predaju vježbanju, vjerojatnije će naići na prihvaćanje takvoga stava jer se on podudara s idejom da će vježbanje učenika učiniti boljim glazbenikom i dati rezultate (Asmus, 1986b: 274). Naprotiv, oni nastavnici koji promoviraju sposobnost u vezi s atribucijama sugeriraju da postoje urođene karakteristike koje samo neki posjeduju, a omogućuju im da 
budu dobri glazbenici (Asmus, 1986b: 274). Ako se u nastavi stvara natjecateljska atmosfera ili nastavnici nagrađuju učenike za postignuća za koje nije zaslužan uložen trud, oni će usvajati unutrašnje-nepromjenjive atribucije sposobnosti (West, 2013: 16) koje su općeprihvaćene u društvu kada se govori o glazbenim postignućima jer se ona neposredno povezuju s glazbenom darovitošću. Takve atribucije nisu povoljne za glazbeno obrazovanje i uvažavajući psihološke reperkusije nastavnikova djelovanja $u$ nastavi glazbe, treba promišljati o izravnim i neizravnim porukama koje se oblikovanjem nastavnoga procesa i nastave klime šalju učenicima/ studentima.

Teorija ciljne orijentacije u kontekstu učenja glazbe

Temeljna je pretpostavka socijalno-kognitivističkih teorija motivacije kako je "motivirano ponašanje uvjetovano postavljenim ciljevima i percepcijom mogućnosti njihova objašnjenja" (Vizek Vidović, Rijavec, Vlahović-Štetić i Miljković, 2003: 267). Učenici koji imaju orijentaciju prema ciljevima učenja (engl. task orientation; mastery) teže k razvijanju novih vještina, nastoje razumjeti svoj rad, poboljšati svoju kompetentnost ili postići osjećaj ovladavanja na temelju standarda koje sami određuju (Ames, 1992: 262). Istraživanja su pokazala kako je orijentacija prema ciljevima učenja povezana s pozitivnim, adaptivnim obrascem atribucija, a učenici su skloniji vidjeti jaku vezu između uloženoga truda i ishoda učenja, stvaraju više atribucija uloženoga truda za uspješnost i neuspješnost (Maehr, Pintrich \& Linnenbrink, 2002: 360) te imaju tendenciju rabiti dublje, djelotvornije strategije učenja i mnogo učinkovitije primjenjuju ono što su naučili (engl. mastery-oriented pattern). Nasuprot njima, učenici koji imaju orijentaciju prema ciljevima izvođenja (engl. ego goal orientation; performance- 
approach goal) usmjereni su na svoju sposobnost i osjećaj vlastite vrijednosti, a sposobnost se dokazuje kada se radi nešto bolje nego drugi, pokušavanjem nadmašivanja normativa standarda izvođenja ili postizanjem uspjeha s malo uloženoga truda (Ames, 1992: 262). Ciljevi izvođenja tiču se postizanja pozitivnih i izbjegavanja negativnih sudova o kompetenciji. Kada su učenikovi ciljevi i uvjerenja o vjerojatnosti njihovoga uspjeha u pitanju, oni koji sebi postavljaju ciljeve izvođenja ranjiviji su i razvijaju reakcije bespomoćnosti, posebno kada su usmjereni na mogućnost neuspjeha (Dweck \& Leggett, 1988: 256).

$\mathrm{Na}$ isti se način učenici/studenti mogu odrediti prema ciljevima učenja glazbe i time odrediti svoju motivaciju za kontinuirani razvoj glazbenih kompetencija. Istraživanja među instrumentalistima srednjoškolske dobi pokazala su pozitivnu korelaciju između orijentacije prema ciljevima učenja i vremena te truda utrošenoga za vježbanje sviranja, procjenjivanja izvedbe (Schmidt, 2005:134), intrinzične motivacije te samoregulacije (Bailey, 2006, prema West, 2013: 14). Zanimljiv je Sendeneov (1997, prema West, 2013: 13) nalaz kako motivacija učenika za sviranje instrumenta značajno korelira sa samopouzdanjem u sviranju, orijentacijom prema ciljevima učenja i učenikovom percepcijom da njegov učitelj glazbe ima istu ciljnu orijentaciju. Stoga, nastavnici glazbe mogu pomoći učenicima da postanu orijentirani prema ciljevima učenja time što su i sami orijentirani na ciljeve učenja te na način da procjenjuju učenike temeljem njihova uloženoga truda (West, 2013: 14). 
Teorija očekivanja-vrednovanja u kontekstu učenja glazbe

Među različitim pristupima kojima se pokušava objasniti na koji način motivacija djeluje na izbor aktivnosti, upornost $u$ aktivnosti i učinak uloženoga truda ističe se teorija očekivanja-vrednovanja (engl. expectancyvalue), a ona uključuje uvjerenja o sposobnosti, očekivanje uspjeha i subjektivno vrednovanje zadatka. Uvjerenja o sposobnosti podrazumijevaju percepciju pojedinca o svojoj trenutačnoj kompetentnosti za pojedinu aktivnost, očekivanja su usmjerena na očekivanje uspjeha u budućnosti, a subjektivno vrednovanje podrazumijeva vrijednost postignuća, intrinzičnu vrijednost zadatka, korisnost zadatka i cijenu uloženoga truda. Očekivanje i vrednovanje mogu biti pod utjecajem uvjerenja o sposobnostima, percipiranoj težini različitih zadataka te ciljeva, samopoimanja i emocionalnih sjećanja pojedinca, njegova ranijega iskustva i različitih utjecaja u procesu socijalizacije (Wigfield \& Eccles, 2000: 69).

Hallam (2006: 144) smatra da bi se kao teorijski okvir za angažman u glazbi mogao upotrijebiti upravo model teorije očekivanja-vrednovanja. Prema Hallam (2006: 145) spomenuti model ima tri glavne komponente među kojima postoji složena interakcija:

a) Vrijednosna komponenta $u$ glazbenom obrazovanju važna je za procese motivacije jer se ona referira na vrijednost glazbenoga obrazovanja u određenoj kulturi i društvu na globalnoj razini, a onda i na subjektivnoj razini svakoga učenika/studenta u odnosu na željenu razinu postignuća u glazbi. Dakle, intrinzična vrijednost svakoga zadatka i korisnost zadatka za buduće ciljeve u glazbi uvjetuje i procjenu pojedinca koliko će se odricati i uložiti truda u postizanje postavljenih ciljeva u glazbi. 
b) Komponenta očekivanja povezana je s uvjerenjima studenata o vlastitoj sposobnosti da izvedu zadatak, njihovim sudovima o samoučinkovitosti i kontroli te očekivanjem uspjeha (Hallam, 2006: 149). Kada student prilazi glazbenom zadatku, on oblikuje očekivanja o tome koliko će dobro moći konkretan zadatak i realizirati, a očekivanja će se temeljiti na njegovim ranijim realizacijama. Uvjerenja o samoučinkovitosti mogu poboljšati ili pogoršati izvedbu preko njihovoga djelovanja na kognitivne, afektivne ili motivacijske procese (Bandura, 1989: 729). Što su jača uvjerenja u njihove sposobnosti, to se osobe više trude i upornije su te biraju zahtjevnije ciljeve i snažnija je njihova predanost tim ciljevima, a izazovni ciljevi povećavaju razinu motivacije i postignuća izvedbe (Bandura, 1989: 730).

c) Afektivna komponenta povezana je s učenikovim osjećajem o sebi, njegovom potrebom da održi samopoštovanje, njegovim emocionalnim reakcijama na zadatak te $s$ anksioznošću $u$ vezi $s$ izvođenjem glazbe. Atribucije postignuća učenika određuju emocionalne reakcije koje mogu izravno pokrenuti aktivnost (Kolić-Vehovec, 1998: 116). Kako bi učenici bili motivirani za glazbenu aktivnost, oni je moraju pozitivno vrednovati i vjerovati kako će biti uspješni u njoj u budućnosti (Cogdill, 2014: 50) te trebaju istinski uživati u aktivnosti (Wigfield \& Eccles, 2000: 72).

\section{IMPLIKACIJE ZA NASTAVU GLAZBE NA UČITELJSKIM STUDIJIMA}

Iako su prikazane teorije motivacije pokušale uzeti u obzir različite varijable, nastavnikova osobnost, interakcija sa studentima, strategije poučavanja, nastavna klima i brojni drugi čimbenici utječu na studentovu motivaciju te nije moguće kontrolirati bezbrojne interventne varijable koje su 
neizbježne kada se govori o složenom konstruktu kao što je motivacija (West, 2013: 17). Stoga, teorijski pristupi motivaciji mogu poslužiti za izdvajanje varijabli koje se odnose na specifičan kontekst nastave glazbe kako bi se uputilo na one komponente motivacije na koje nastavnik može djelovati tijekom glazbenoga obrazovanja na učiteljskom studiju.

\section{Percepcija sposobnosti i uloženi trud}

Sve tri izložene teorije motivacije kao važne komponente ističu percepciju o vlastitim sposobnostima za glazbeni zadatak te ulaganje truda učenika i studenta u procesu učenja glazbe. Austin i Vispoel (1998: 41) ističu kako adolescenti vrlo usko shvaćaju glazbene sposobnosti kao vrhunske glazbene vještine te je zbog toga poželjno da nastavnici glazbe u nastavu uključe različite glazbene aktivnosti kako bi studenti pronašli onu glazbenu aktivnost u kojoj se osjećaju kompetentno u glazbi. Nastavnici trebaju prenositi uvjerenje kako je napredak moguć kao rezultat pruženih prilika, poduke $\mathrm{i}$ iskustva te na taj način studenti mogu postati otporni na negativne učinke atribucija sposobnosti (Austin i Vispoel, 1998: 41).

Istraživanja su pokazala da je orijentacija prema ciljevima izvođenja povezana s maladaptivnim obrascem atribucija bespomoćnosti jer učenici rabe atribucije sposobnosti i za uspjeh i neuspjeh, a sposobnost smatraju stabilnom, nepromjenjivom (Maehr et al., 2002: 360). U tom se kontekstu može promatrati i veza između njihova shvaćanja inteligencije, izbora ciljeva te shvaćanja prirode glazbenih sposobnosti. Kada studenti shvaćaju inteligenciju kao stabilnu i nepromjenjivu, skloniji su usvojiti ciljeve izvođenja, dok oni koji smatraju da je inteligenciju moguće povećati, imaju tendenciju biranja ciljeva učenja (Dweck \& Leggett, 1988: 256). Ako stav o promjenjivosti inteligencije proširimo na sve druge kapacitete i sposobnosti 
osobe, pa i na glazbene sposobnosti, onda se i stav studenata s obzirom na usvajanje ciljeva učenja glazbe i važnost ulaganja truda može gledati iz iste perspektive. Tako će stav studenata o prirodi glazbenih sposobnosti i važnosti uloženoga truda postati temelj izbora ciljeva izvođenja ili ciljeva učenja. Učenici su više motivirani kada uče na nastavi u kojoj ih se ne razlikuje prema sposobnostima (West, 2013: 13) pa je poželjno njegovati orijentaciju ciljeva učenja koja ima adaptivni obrazac atribucija i pozitivan utjecaj koji će pomoći studentu da se više trudi, ustraje i bude uspješniji u akademskim zadatcima (Maehr et al., 2002: 361). Dakle, motivacija za učenje glazbe bit će veća ako studenti vjeruju da su dovoljno sposobni za glazbena postignuća koja se pred njih stavljaju, ako se trude naučiti i više od očekivanoga i usvoje ciljeve učenja te što su uspješniji u glazbi.

Najvažniji je element uspješnosti u glazbenom obrazovanju uz glazbene sposobnosti ulaganje truda. Zato nastavnici moraju biti pažljivi i pitati se koju poruku šalju studentima i kako će se to odraziti na njihove atribucije i buduće ulaganje truda. Ako se studentova ukupna sposobnost vrednuje više nego napredovanje, to može poslati poruku studentu kako je sposobnost nepromjenjiva, što vodi prema maladaptivnim atribucijama $u$ situacijama neuspjeha kao što je pripisivanje neuspjeha unutrašnjim, nekontrolabilnim dimenzijama (Maehr et al., 2002: 365).

\section{Uspješnost $i$ afektivna komponenta}

Izložene teorije motivacije istaknule su i važnost uspješnosti studenata tijekom glazbenoga obrazovanja za motivaciju za nastavak učenja glazbe. Najbolji ishod učenja za studenta može se očekivati kada mu se zadaje zadatak koji je odgovarajuće težine ( $u$ dosegu studenta $u$ odnosu na njegove 
sposobnosti i do sada razvijenih vještina) te je studentu izazovan, zanimljiv i pričinjava mu zadovoljstvo. Također, važno je da student shvaća vrijednost savladavanja zadatka za njegovo učenje te za to ima dovoljno vremena (Austin i Vispoel, 1998: 42). Maehr i suradnici (2002: 365) predlažu da nastavnik zadaje znatne količine raznovrsnih zadataka koji mogu pomoći pri zadržavanju zainteresiranosti studenata, da promišljeno prezentira pojedine zadatke kako bi studenti uvidjeli osobnu važnost i smislenost sadržaja njihovog učenja te da omogući studentima odabir određenog zadatka među ponuđenima, što će omogućiti zadovoljenje njihove potrebe za autonomijom učenja, a sve u cilju povećanja osobne vrijednosti zadataka te, posljedično, povećanja intrinzične motivacije studenata te olakšavanja njihova usvajanja orijentacije prema ciljevima učenja.

Afektivna komponenta teorije očekivanja-vrednovanja povezana je s uspješnošću studenata i mišljenjem studenata o tome što uzrokuje njihov uspjeh ili neuspjeh. Weiner (1986: 162) je objasnio kako pripisivanje uspjeha i neuspjeha stabilnim ili nestabilnim, kontrolabilnim ili nekontrolabilnim te unutrašnjim ili vanjskim čimbenicima utječe na psihološke afektivne posljedice koji mogu biti: sreća, ponos, samopouzdanje, nadanje, opuštenost, iznenađenost, zahvalnost, tuga, frustriranost, bespomoćnost, sram, krivnja, ljutnja, žaljenje. Kada student doživljava uspjeh, bit će sretan i u budućnosti očekuje uspjeh. Ako student svoj neuspjeh pripisuje nečemu nestabilnom, na primjer lošoj sreći, to se ne mora više događati u budućnosti, stoga se njegov osjećaj frustracije ne mora ponoviti jer očekivanja u vezi $\mathrm{s}$ budućim izvođenjima neće biti ugrožena. Ali, ako se neuspjeh pripisuje stabilnim čimbenicima, kao što je manjak sposobnosti, onda se može očekivati neuspjeh (Weiner, 1986: 170) i posljedično, negativne afektivne (primjerice 
bespomoćnost) i bihevioralne posljedice (primjerice smanjivanje ulaganja truda). Istraživanja emocionalne reakcije na uspjeh i neuspjeh pokazala su da osjećaj ljutnje, uzrujanosti i krivice ili povratna informacija o neuspjehu vjerojatno vode prema pozitivnim odgovorima za budući rad (Hallam, 2006: 152). Međutim, ako su odgovori na neuspjeh okarakterizirani kao stid ili nelagoda pred drugima, manje je vjerojatno da će se pozitivno odraziti na budući rad, što se češće javlja kod onih koji svoj neuspjeh tumače kao manjak sposobnosti (Hallam, 2006: 153).

Upravo je nastavnik onaj koji može ublažiti posljedice povremenih neuspjeha, platoa u učenju i privremenih zastoja koji se uobičajeno događaju u glazbenom obrazovanju usporedno s uspješnošću. Povratna informacija o glazbenom izvođenju koju nastavnik daje studentu može ublažiti nepovoljne utjecaje neuspješne izvedbe na afektivna stanja studenta koja nisu povoljna za njegov budući angažman u glazbi. Kada student nije bio uspješan $\mathrm{u}$ izvođenju glazbe, nastavnik treba dati povratnu informaciju o neuspjehu, ali pri tom ne bi smio upućivati na manjak sposobnosti niti bi smio postidjeti studenta zbog neuspjeha te bi trebao izbjegavati socijalne usporedbe kod izvođenja. U slučaju studentova neuspješnoga izvođenja glazbenoga zadatka nastavnik glazbe na učiteljskom studiju trebao bi uputiti studente na kontrolabilne (npr. trud, vježbanje) i nekontrolabilne elemente (npr. loše raspoloženje). Nadalje, trebao bi educirati studente o prirodi i mogućim posljedicama straha od javnoga nastupa (treme) jer studenti glazbeno izvođenje pred nastavnikom i kolegama doživljavaju kao javni nastup (Ercegovac-Jagnjić i Nikolić, 2010: 90).

U nastavi glazbe potrebna je stalna evaluacija kako bi se stjecala znanja o glazbi i razvijale glazbene vještine, ali za stvaranje prikladnih 
atribucija kod studenata, koje će voditi prema budućoj uspješnosti u glazbi, pogodna je isključivo objektivna evaluacija (Asmus, 1986a: 82). Zaslužene pohvale ključne su za razvoj samopouzdanja, pogotovo u početku učenja glazbe. Glazbeno izvođenje pred drugima neizbježno prati usporedba vlastite izvedbe u odnosu na ostale vršnjake i može djelovati na smanjenje motivacije kod studenata (Austin i Vispoel, 1998: 42). Nastavnici mogu ublažiti spomenutu pojavu tako da provode obazrivu evaluaciju koja neće isticati sposobnosti te izbjegavaju situacije natjecanja među studentima koji se razlikuju u vještini, samopouzdanju ili iskustvu (Austin i Vispoel, 1998: 42). Studente treba poticati da prilikom glazbenoga izvođenja uče jedni od drugih te jedni druge doživljavaju kao suradnike, a ne prijetnju budućem uspjehu (Austin i Vispoel, 1998: 42).

Identificiranje samoga sebe kao svojevrsnoga glazbenika zahtijeva određenu predanost glazbi, što zauzvrat zahtijeva aktivan glazbeni angažman koji izaziva uživanje. Nastavnici glazbe ključni su u određivanju obujma glazbenih aktivnosti u kojem će one izazivati uživanje te u uspostavljanju njihove odgovarajuće razine kako bi aktivnosti bile izazovne, a studenti uspješni u njihovom izvođenju.

\section{Vrijednosna komponenta}

Vrijednosna komponenta kod studenata učiteljskoga studija prije svega odnosi se na percepciju važnosti i vrijednosti glazbenoga obrazovanja u školi, stoga i njihova glazbenoga obrazovanja kao budućih učitelja, a onda i važnosti stjecanja specifičnih glazbenih kompetencija. Studenti imaju varijabilno zanimanje za učenje glazbe, bilo da se radi o učenju glazbe uopće ili o pojedinim zadacima učenja, što je razumljivo s obzirom na heterogenost samoga učiteljskog studija u područjima obrazovanja i afiniteta pojedinca 
prema svakom od njih. Značajna je i varijabilnost shvaćanja korisnosti pojedinih zadataka glazbenoga obrazovanja za buduće ciljeve, prvo u okviru stjecanja glazbenih znanja i vještina, zatim metodičkih kompetencija, pa onda i ukupne kompetencije budućeg učitelja. Studenti učiteljskoga studija mogu različito vrednovati područje njihove glazbene kompetentnosti u odnosu na važnost kompetentnosti u drugim podučjima obrazovanja na studiju. Osim toga, studenti mogu različito vrednovati glazbene kompetencije od metodičkih kompetencija za vođenje nastave glazbe, a varijabilno je i vrednovanje više područja glazbenih kompetencija (sviranje, pjevanje, analitičko slušanje glazbe, znanja o glazbi, glazbena kreativnost). Kada se govori o cijeni uloženoga truda kod studenata učiteljskoga studija, mora se istaknuti kako oni studiraju heterogeni studij pa se glazba uči uz druga područja učiteljevih stručnih kompetencija te će u tom elementu doći do izražaja studentova procjena koliko mu se isplati uložiti vremena i truda upravo za glazbu u odnosu na druga područja, kao i njegov stav o važnosti glazbene kompetencije učitelja. Uloga nastavnika glazbe ključna je za razvoj pozitivnih stavova studenata prema glazbenom obrazovanju i stjecanju kompetencija za vođenje nastave glazbe u razredu, stoga nastavnici trebaju biti upoznati s osobitostima stavova kao psihološkoga koncepta (Nikolić, 2017b).

\section{ZAKLJUČAK}

Studenti učiteljskoga studija mogu biti manje ili više motivirani za različite nastavne predmete u programu studija pa tako i za učenje glazbe. Osim individualnih razlika među studentima, motivacija ovisi o socijalnom okruženju i nastavnoj klimi u kojoj se nastava glazbe odvija. Socijalni 
kontekst koji čine ostali studenti i nastavnik može njegovati unutrašnju motivaciju te rezultirati zadovoljavajućim angažmanom za stjecanje i razvoj kompetencija za poučavanje glazbe ili može potisnuti unutarnju motivaciju na način da se student sve manje trudi i sve je nezadovoljniji.

Dosadašnja istraživanja bavila su se motivacijom za učenje glazbe $u$ djetinjstvu i adolescenciji $u$ instrumentalnoj nastavi i sudjelovanjem $u$ orkestrima i glazbenim sastavima. Međutim, učenje glazbe kao profesionalne kompetencije kod budućih učitelja primarnoga obrazovanja nije do sada privuklo pozornost istraživača. Upravo je nezadovoljavajuća situacija u nastavi glazbe u primarnom obrazovanju kod nas i u svijetu razlog zašto bi trebalo istražiti na koji se način može tijekom studija djelovati na stjecanje i razvoj kompetencija za poučavanje glazbe. U tom kontekstu, važno je istraživati motivaciju za učenje glazbe kao jedan od značajnih čimbenika angažmana studenta tijekom studija, ali i kao pretpostavku angažmana budućega učitelja u nastavi glazbe u razredu.

$\mathrm{U}$ ovome radu predstavljene su tri teorije motivacije koje se konceptualno mogu primijeniti na motivaciju studenata, budućih učitelja za učenje glazbe na studiju, a to su atribucijska teorija, teorija ciljne orijentacije i teorija očekivanja-vrednovanja. Sve tri spomenute teorije ističu varijable percepcije sposobnosti studenata, ulaganja truda i uspješnosti, dok atribucijska teorija i teorija očekivanja-vrednovanja ističu i afektivnu komponentu motivacije, a teorija očekivanja-vrednovanja uz nabrojane komponente motivacije ističe još i vrijednosnu komponentu koja je značajan element motivacije u glazbenom obrazovanju studenata učiteljskih studija. Iako su sve tri teorije motivacije upotrijebljene kako bi se objasnile psihološke komponente motivacije za učenje glazbe na učiteljskom studiju, 
upravo je teorija očekivanja-vrednovanja obuhvatila najviše varijabli važnih za glazbeno obrazovanje budućih učitelja.

Istraživanja motivacije za učenje glazbe pokazala su da nastavnici mogu djelovati na povećanje motivacije za učenje glazbe i to kreiranjem nastavnoga procesa i nastavne klime u kojoj nastavnik promišlja o izravnim i neizravnim porukama koje šalje studentima. Nastavnici glazbe na učiteljskim studijima mogu djelovati na povećanje motivacije za učenje glazbe na sljedeće načine:

- ohrabrivati studente na usvajanje atribucija vezanih uz ulaganje truda

- kod studenata poticati razvijanje ciljne orijentacije prema ciljevima učenja

- omogućiti studentima uspješnost u glazbi kako bi razvili samoučinkovitost u glazbi

- omogućiti brojne i različite zadatke kako bi studenti pronašli glazbene aktivnosti u kojima mogu biti uspješni i u kojima mogu uživati te omogućiti studentima izbor među ponuđenim zadatcima

- ocjenjivati studente temeljem uloženoga truda, a ne na temelju sposobnosti

- sustavno djelovati na pozitivno vrednovanje svakoga glazbenog zadatka, ali i stjecanja i razvoja glazbenih kompetencija, kompetencija za poučavanje glazbe te vrijednosti glazbenoga obrazovanja uopće.

Kako bi se stekle spoznaje o prirodi i ulozi motivacije za učenje glazbe kod studenata, budućih učitelja, potrebna su empirijska istraživanja koja bi mogla odgovoriti na pitanja:

- kakva je motivacija studenata za učenje glazbe kada se upišu na učiteljski studij i mijenja li se ona tijekom studija 
- kakva je veza između glazbenoga obrazovanja i iskustva aktivnoga muziciranja prije studija i motivacije za učenje glazbe na studiju

- koji elementi nastave glazbe na studiju potiču studente na učenje glazbe i bavljenje glazbom

- u kojoj mjeri motivacija za učenje glazbe utječe na glazbenu uspješnost studenata učiteljskih studija

- kakva je veza između motivacije za učenje glazbe na studiju i motivacije za podučavanje glazbe u školi te jesu li motiviraniji studenti bolji učitelji u praksi.

Istraživanje motivacije kao čimbenika glazbenoga obrazovanja budućih učitelja trebalo bi potaknuti nastavnike učiteljskih studija, ali i druge nastavnike glazbe da u svom radu uz poučavanje znanja o glazbi i glazbenih vještina obraćaju pozornost na psihološke aspekte učenja glazbe kako bi poticali svoje učenike i studente da se bave glazbom, cijene glazbu i glazbeno obrazovanje te uživaju u muziciranju. Neki nastavnici glazbe nisu svjesni složenoga psihološkog koncepta koji oblikuje motivaciju i učenje. Učitelji i nastavnici glazbe na prvo mjesto stavljaju glazbeno postignuće učenika i studenata te često svoje podučavanje temelje na vlastitom iskustvu metodičkih pristupa njihovih bivših učitelja glazbe, na metodičkoj praksi sa studija i vlastitom iskustvu poučavanja. Upitna su znanja učitelja i nastavnika glazbe iz područja psihologije i pedagogije koja su im neophodna kako bi uz stručno-glazbene kompetencije kod učenika i studenata, koji uče glazbu, razvijali i izgrađivali njihov glazbeni identitet, kao i njihovu osobnu dobrobit od učenja glazbe i razvijanje motivacije da se i dalje bave glazbom te postižu akademska postignuća u glazbi i uživaju u muziciranju. Ako bi se tijekom studija i u oblicima cjeloživotnoga obrazovanja nastavnici i učitelji glazbe 
više obrazovali u području psihologije i pedagogije glazbe, mogli bi primjenjivati spoznaje o mogućnostima djelovanja na motivaciju kod učenika i studenata kako bi se podržale njihove težnje za buduće bavljenje glazbom.

\title{
MOTIVATION OF STUDENTS OF TEACHER STUDIES TO LEARN MUSIC THROUGH THE LENS OF MOTIVATION THEORIES
}

\begin{abstract}
This paper discusses motivation of students to learn music as a part of the complusory music courses in undergraduate teacher studies. Its purpose is to provide an insight into the motivation factors behind students' learning of music, thus setting a ground for more efficient music lessons and better access to music teaching skills for future teachers. It presents three motivation theories applicable to the discussion of students' motivation: Attribution Theory, Achievement Goal Orientation Theory, and Expectancy-Value Theory. When these three theories are applied to music learning as a part of teacher studies, the following variables appear important: students' perception of their own abilities, their effort, success, as well as the affective and value component of their motivation. The theory which encompasses the greatest number of elements crucial for music education of students in teacher studies is the Expectancy-Value Theory, which could be used in future research. The review of motivation research in music education has shown that teachers can be an influential factor in increasing students' motivation by: encouraging students to adopt effortbased attributions, encouraging them to orient themselves towards the task orientation, helping them to become successful in music, giving them a plethora of various music tasks, appreciating their efforts, and cultivating values that will form positive attitudes of students towards music education.
\end{abstract}

KEY WORDS: effort-based attribution, music education, motivation to learn music, perception of music abilities, students of teacher studies. 


\section{REFERENCE}

Alexander, D. L. (2015). Intrinsic motivation: The key to fully engaged music students. Pristupljeno 18.3.2018. na:

https://www.academia.edu/29793887/Intrinsic_Motivation_The_Key_ to_Fully_Engaged_Music_Students

Ames, C. (1992). Classrooms: Goals, structures, and student motivation. Journal of Educational Psychology, 84, 261-271.

Arnold, J. A. (1997). A Comparison of attributions for success and failure in instrumental music among sixth-, eighth-, and tenth-grade students. Update: Applications of Research in Music Education, 15(2), 19-23.

Asmus, E. P. (1985). Sixth Graders' Achievement Motivation: Their Views of Success and Failure in Music. Bulletin of the Council for Research in Music Education, 85, 1-13.

Asmus, E. P. (1986a). Achievement Motivation Characteristics of Music Education and Music Therapy Students as Identified by Attribution Theory. Bulletin of the Council for Research in Music Education, 86, 71-85.

Asmus, E. P. (1986b). Student beliefs about the causes of success and failure in music: A study of achievement motivation. Journal of Research in Music Education, 34(4), 262-278.

Asmus, E. P., \& Harrison, C. (1990). Characteristics of motivation for music and musical aptitude of undergraduate nonmusic majors. Journal of Research in Music Education, 3, 258-268.

Atkinson, J. W. (1964). An Introduction to Motivation. Princeton, NJ: Van Nostrand. 
Austin, J. R. (1988). The effect of music contest format on self-concept, motivation, achievement, and attitude of elementary band students. Journal of Research in Music Education, 36, 95-107.

Austin, J. R. (1991). Competitive and non-competitive goal structures: An analysis of motivation and achievement among elementary band students. Psychology of Music, 19(2), 142-158.

Austin, J. R., \& Vispoel, W. P. (1998). How American adolescents interpret success and failure in classroom music: Relationships among attributional beliefs, self-concept and achievement. Psychology of Music, 26, 26-45.

Bačlija Sušić, B. i Županić Benić, M. (2017). Different teaching methods in music education and achievement motivation. In: L. Gómez Chova, A. López Martínez, I. Candel Torres, IATED Academy (Eds.), ICERI2017 Proceedings 10th International Conference of Education, Research and Innovation (pp. 6742-6751). Seville, Spain: IATED Academy.

Bandura, A. (1989). Regulation of cognitive processes through perceived self-efficacy. Developmental Psychology, 25(5), 729-735.

Bandura, A. (1994). Self-efficacy. In: V. S. Ramachaudran (Ed.), Encyclopedia of human behavior (Vol. 4, pp. 71-81). New York: Academic Press.

BERA Music Education Review Group (2004). Mapping music education research in the UK. Psychology of Music, 32(3), 239-290.

Bogunović, B. (2005). Atribucioni model tumačenja postignuća u muzičkom obrazovanju. Nastava $i$ vaspitanje, 54(4-5), 358-357. 
Bogunović, B. (2010). Muzički talenat i uspešnost. Beograd: Fakultet muzičke umetnosti i Institut za pedagoška istraživanja

Burak, S. (2014). Motivation for instrument education: A Study with the perspective of expectancy-value and flow theories. Eurasian Journal of Educational Research, 55, 123-136.

Chirico, A., Serino, S., Cipresso, P., Gaggioli, A., \& Riva, G. (2015). When music "flows". State and trait in musical performance, composition and listening: a systematic review. Frontiers in Psychology, 6, Article 906. Pristupljeno 15.2.2018. na: http://doi.org/10.3389/fpsyg. 2015.00906

Cogdill, S. H. (2014). Applying Research in Motivation and Learning to Music Education: What the Experts Say. Update: Applications of Research in Music Education, 33(2), 49-57.

Corenblum, B., \& Marshall, E. (1998). The band played on: Predicting students' intentions to continue studying music. Journal of Research in Music Education, 46, 128-140.

Csikszentmihalyi, M. (1991). Flow: The Psychology of Optimal Experience. New York: Harper \& Row.

Custodero, L. (2011). The call to create: Flow experience in music and learning and teaching. In: D. Hargreaves, D. Miell \& R. MacDonald (Eds.), Musical Imaginations Multidisciplinary perspectives on creativity, performance and perception (pp. 369-384). Oxford: Oxford University Press.

Deci, E. L., \& Ryan, R. M. (1985). Intrinsic motivation and selfdetermination in human behavior. New York, NY: Plenum Press. 
Dibben, N. (2006). The socio-cultural and learning experiences of music students in a British university. British Journal of Music Education, 23(1), 91-116.

Dweck, C. S., \& Leggett, E. L. (1988). A social-cognitive approach to motivation and personality. Psychological Review, 95(2), 256-273.

Eccles, J. S., \& Wigfield, A. (2002). Motivational beliefs, values and goals. Annual Review of Psychology, 53(1), 109-132.

Ercegovac-Jagnjić, G. i Nikolić, L. (2010). Trema studenata prilikom sviranja i pjevanja. U: T. Vrandečić i A. Didović (ur.), Glas i glazbeni instrument u odgoju i obrazovanju (str. 90-102). Zagreb: Grafbiro Dominić.

Evans, P. (2015). Self-determination theory: An approach to motivation in music education. Musicae Scientiae, 19(1), 65-83.

Evans, P., \& Bonneville-Roussy, A. (2015). Self-determination motivation for practise in university music students. Psychology of music, 44(5), 1095-1110.

Gaunt, H., \& Hallam, S. (2009). Individuality in the learning of musical skills. In: S. Hallam, I. Cross, \& M. Thaut (Eds.), The Oxford handbook of music psychology (pp. 274-284). New York, NY: Oxford University.

Hallam, S. (2006). Music psychology in education. London: Institute of education, University of London.

Hallam, S. (2013). What predicts level of expertise attained, quality of performance, and future musical aspirations in young instrumental players?. Psychology of Music, 41(3), 267-291. 
Hallam, S., Creech, A., Papageorgi, I., Gomes, T., Rinta, T., Varvarigou, M., \& Lanipekun, J. (2016). Changes in motivation as expertise develops: Relationships with musical aspirations. Musicae Scientiae, 20(4), 528550.

Hendricks, K. S. (2016). The sources of self-efficacy: Educational research and implications for music. Update: Applications of Research in Music Education 35(1), 32-38.

Hruska, B. J. (2011). Using mastery goals in music to increase student motivation. Update: Applications of Research in Music Education, 30(1), 3-9.

Iusca, D. (2015). The relationship between flow and music performance level of undergraduates in exam situations: The effect of musical instrument. Procedia - Social and Behavioral Sciences, 177, 396-400.

Klinedinst, R. E. (1991). Predicting performance achievement and retention of fifth-grade instrumental students. Journal of Research in Music Education, 39, 225-238.

Kolić-Vehovec, S. (1998). Edukacijska psihologija. Rijeka: Filozofski fakultet.

Leung, B. W. (2008). Factors affecting the motivation of Hong Kong primary school students in composing music. International Journal of Music Education, 26(1), 47-62.

Levitin, D. J. (2012). What does it mean to be musical?. Neuron, 73(4), 633637.

MacIntyre, P. D., Schnare, B, \& Ross, J. (2017). Self-determination theory and motivation for music. Psychology of Music, O(0), 1-17. 
Pristupljeno 16.3.2018. na: http://journals.sagepub.com/doi/10.1177/ 0305735617721637

Maehr, M. L., Pintrich, P. R., \& Linnenbrink, E. A. (2002). Motivation and achievement, In:R. Colwell, \& C. Richardson (Eds.): The new handbook of research on music teaching and learning (pp. 348-372). Oxford: Oxford University Press.

Marjoribanks, K., \& Mboya, M. (2004). Learning environments, goal orientations, and interest in music. Journal of Research in Music Education, 52(2), 155-166.

McCormick, J., \& McPherson, G. E. (2007). Expectancy-value motivation in the context of a music performance examination. Musicae Scientiae, 11(2), 37-52.

McPherson, G. E., \& O’Neill, S. A. (2010). Students' motivation to study music as compared to other school subjects: A comparison of eight countries. Research Studies in Music Education, 32, 101-137.

McPherson, G. E., Osborne, M. S., Barrett, M. S., Davidson, J. W., \& Faulkner, R. (2015). Motivation to study music in Australian schools: The impact of music learning, gender, and socio-economic status. Research Studies in Music Education, 37(2), 141-160.

McPherson, G. E. \& McCormick, J. (2006). Self-efficacy and music performance. Psychology of Music, 34(3), 322-336.

Miksza, P., Tan, L., \& Dye, C. (2016). Achievement motivation for band: A cross-cultural examination of the $2 \times 2$ achievement goal motivation framework. Psychology of Music, 44(6), 1372-1388. 
$\mathrm{Ng}$, C. (2015). Australian primary students' motivation and learning intentions for extra-curricular music programmes. Music Education Research, 19(3), 276-291.

Nielsen, S. G. (2004). Strategies and self-efficacy beliefs in instrumental and vocal individual practice: a study of students in higher music education. Psychology of Music, 32(4), 418-431.

Nikolić, L. (2014). Obrazovanje budućih učitelja razredne nastave za vođenje pevanja u razredu. U: M. Petrović (ur.), Sociološki aspekt pedagogije $i$ izvođaštva u scenskim umetnostima (str. 81-99). Beograd: Fakultet muzičke umetnosti.

Nikolić, L. (2017a). Evaluacija modela glazbenoga obrazovanja budućih učitelja primarnoga obrazovanja. Školski vjesnik: časopis za pedagogijsku teoriju i praksu, 66(2), 161-179.

Nikolić, L. (2017b). Stavovi o glazbenom obrazovanju kao čimbenik glazbenog obrazovanja budućih učitelja. Metodički ogledi: časopis za filozofiju odgoja, 2, 39-55.

Nikolić, L. (2018). Status glazbenih sposobnosti studenata učiteljskoga studija. U: Radočaj-Jerković, A. (ur.), 2. međunarodni znanstveni $i$ umjetnički simpozij o pedagogiji u umjetnosti - Komunikacija $i$ interakcija umjetnosti i pedagogije (str. 312-332). Osijek: Sveučilište J. J. Strossmayera u Osijeku, Umjetnička akademija u Osijeku.

Nikolić, L. i Ercegovac-Jagnjić, G. (2010). Uloga glazbenih sposobnosti u glazbenom obrazovanju učitelja primarnog obrazovanja. Metodika: časopis za teoriju i praksu metodika u predškolskom odgoju, školskoj i visokoškolskoj izobrazbi, 11(20), 23-33. 
O'Neill, S. (1999). Flow theory and the development of musical performance skills, Bulletin of the Council for Research in Music Education, 141, 129-134.

Ryan, R. M., \& Deci, E. L. (2000). Self-determination theory and the facilitation of intrinsic motivation, social development, and wellbeing. The American Psychologist, 55, 68-78.

Schatt, M. D. (2011). Achievement motivation and the adolescent musician: A synthesis of the literature. Research and Issues in Music Education, 9(1), pp. np. Pristupljeno 16.2.2018. na: https://openmusiclibrary. org/article/107772/

Schmidt, C. P. (2005). Relations among motivation, performance achievement, and music experience variables in secondary instrumental music students. Journal of Research in Music Education, $53,134-147$.

Schneider Grings, A. F., \& Hentschke, L. (2015). Attributional Theory in investigating public music performance in higher music education. International Journal of Music Education, 35(1), 31-46.

Sinnamon, S., Moran, A., \& O'Connell, M. (2012). Flow among musicians. Measuring peak experiences of student performers. Journal of research in Music Education, 60(1), 6-25.

Torres Delgado, G. (2017). Intrinsic motivation and flow condition on the music teacher's performance. Research in Pedagogy, 7(1), 145-157.

Vizek Vidović, V., Rijavec, M., Vlahović-Štetić, V. i Miljković, D. (2003). Psihologija obrazovanja. Zagreb: IEP-VERN.

Weiner, B. (1986). An attributional theory of motivation and emotion. New York: Springer-Verlag. 
West, Ch. (2013). Motivating Music Students: A Review of the Literature. Update: Applications of Research in Music Education, 31(2), 11-19.

Wigfield, A., \& Eccles, J. S. (2000). Expectancy-Value Theory of Achievement Motivation. Contemporary Educational Psychology, 25, $68-81$.

Wigfield, A., Eccles, J. S., Yoon, K. S., Harold, R. D., Arbreton, A., Freedman-Doan, K., \& Blumenfeld, P. C. (1997). Change in children's competence beliefs and subjective task values across the elementary school years: A three-year study. Journal of Educational Psychology, 89(3), 451-469.

Winter, N. (2004). The learning of popular music: A pedagogical model for music educators. International Journal of Music Education, 22, 237247.

Woolfolk, A. (2010). Educational psychology. Upper Saddle River, New Jersey: Pearson Education. 